\title{
FINANCIAL ANALYSIS ON AGROFORESTRY SYSTEM OF COFFEE WITH MARRANGO TREE (Aqadirachta excelsa Jack.) IN REJANG LEBONG REGENCY, BENGKULU PROVINCE, INDONESIA
}

\author{
Bambang T. Premono and Sri Lestari* \\ Palembang Environment and Forestry Research Development Institute \\ Jl. Kol. H. Burlian Km 6.5, Punti Kayu, Palembang, Indonesia
}

Received: 23 November 2016, Revised: 30 April 2018, Accepted: 30 April 2018

\begin{abstract}
FINANCIAL ANALYSIS ON AGROFORESTRY SYSTEM OF COFFEE WITH MARRANGO TREE (Azadiracbta excelsa Jack.) IN REJANG LEBONG REGENCY, BENGKULU PROVINCE, INDONESIA. Marrango tree (Azadirachta excelsa Jack.) has been introduced as a shade tree for coffee plantations that also produces valuable timber for construction and energy. This paper analyzed the financial aspect of an agroforestry system of marrango tree and coffee plantations, including observations of land management, costs and revenues, financial feasibility and sensitivity analysis. The study was conducted in Rejang Lebong Regency, Bengkulu Province through field observations and interviews. Data was collected through direct observations, household surveys and in-depth interviews of several key actors to deepen the information and verify the collected data. Descriptive quantitative and financial analyses were employed to analyze the data. The results showed that the land management of marrango tree and coffee plant agroforestry in Rejang Lebong Regency was conducted in the traditional way. However, the agroforestry system of coffee plants and marrango tree was financially feasible at the level of $8 \%$ discounted rate (NPV = 76,250,582 IDR; $\mathrm{BCR}=2.28$ and IRR $=22 \%$ ). This agroforestry system also has good resistance to changes in coffee price, coffee production and marrango tree price. The agroforestry system remained feasible although if coffee production declined by $30 \%$ and timber production declined up to $30 \%$. The changes in coffee production and price were the most influential factors on the feasibility of the agroforestry system. This agroforestry system is beneficial for the farmers. Hence, the local government should encourage the community to apply this system.
\end{abstract}

Keywords: Agroforestry, coffee, financial analysis, marrango tree

ANALISIS FINANSIAL PADA SISTEM AGROFORESTRI KOPI DENGAN KAYU BAWANG (Azadirachta excelsa Jack.) DI KABUPATEN REJANG LEBONG, PROVINSI BENGKULU, INDONESIA. Kayu bawang (Azadirachta excelsa Jack.) telah diperkenalkan sebagai pohon penaung untuk tanaman kopi. Selain itu pobon ini juga menghasilkan kayu yang cukup bernilai terutama untuk kayu pertukangan dan kayu energi. Tulisan ini bertujuan untuk melakukan analisis finansial sistem agroforestri kayu bawang dan tanaman kopi. Termasuk diantaranya melihat pengelolaan lahan yang diterapkan, mengetahui biaya dan pendapatan, kelayakan finansial dan melakukan analisis sensitivitas terhadap sistem agroforestri yang diterapkan. Penelitian ini dilaksanakan di dataran tinggi Kabupaten Rejang Lebong, Bengkulu, dengan metode observasi lapangan dan wawancara. Data dikumpulkan melalui observasi, survei rumah tangga dan wawancara mendalam dengan beberapa aktor kunci untuk. memperdalam informasi dan memverifikasi data yang telah diperoleh. Data dianalisis dengan menggunakan analisis deskriptif kuantitatif dan finansial. Hasil penelitian menunjukkan bahwa pengelolaan agroforestri kopi dengan kayu bawang di Kabupaten Rejang Lebong masib belum intensif. Petani mengelola lahan dengan cara tradisional. Meskipun demikian, sistem agroforestri tanaman kopi dan kayu bawang layak secara finansial pada tingkat faktor diskonto $8 \%$ (NPV = Rp76.250.582; BCR 2,28 dan IRR 22\%). Sistem agroforestri ini juga memiliki ketahanan yang baik terbadap perubahan harga kopi, produksi kopi dan harga kayu bawang. Sistem agroforestri masib layak meski produksi kopi menurun 30\%, dan produksi kayu turun sebesar 30\%. Perubahan produksi dan harga kopi adalah faktor yang paling berpengarub terbadap kelayakan agroforestri tanaman kopi dan kayu bawang. Sistem agroforestri ini menguntungkan bagi petani. Oleh karena itu, pemerintah daerah harus mendorong masyarakat untuk. menerapkan system ini.

Kata kunci: Agroforestri, kopi, analisis finansial, kayu bawang

*Corresponding author: lestari@iuj.ac.jp 


\section{INTRODUCTION}

Coffee is the main commodity at the upland areas of Rejang Lebong Regency, Bengkulu Province especially along the mountainous region of Bukit Barisan Selatan. According to BPS Rejang Lebong (2013), coffee plantations are the major income source for 17,402 households and contributed substantially to the Gross Domestic Product (GDP) of the regency. About $29.99 \%$ GDP came from coffee, while $16.66 \%$ came from 16 other plantation crops in 2012 (BPS Rejang Lebong, 2013). Coffee plantation covers about 23,656 ha with annual production of 14,344 tons (BPS Bengkulu, 2013). Coffee has an important role in the local economy of this area.

Coffee grows well under a canopy of tropical forest plants such as Erythrina lithosperma and Gliricidia sepium (Wrigley, 1888 in Sari, Santoso, \& Mawardi, 2013). The cultivation of coffee under shade tree is a form of agroforestry system which increases the overall yield of the land and also combines the production of agricultural crops and forest plants on the same unit of land (King \& Chandler, 1978). Jose (2009) mentioned that agroforestry system is able to enhance and maintain long-term soil productivity and sustainability, improve air and water quality, and increase biodiversity conservation that in the long run can reduce poverty. Agroforestry can improve the quality of mammal's habitat, so that it can be a strategy for conserving wildlife and protecting biodiversity (Caudill, Declerck, Husband, \& Rica, 2014). Furthermore, agroforestry system can also provide a source of income for farmers. Hence, it can increase food sufficiency for the community (Pandit, Shrestha, \& Bhattarai, 2014). The use of shading tree improve coffee beans' productivity and enhance soil nutrient cycle (Evizal, Tohari, Prijambada, \& Widada, 2012; Perfecto, Rice, Greenberg, \& Voort, 1996; Lin, 2008). Furthermore, Muschler, (2008) explained that there is a substantial improvement of coffee quality, such as higher weights of fresh fruits, larger beans, and higher rating for visual appearance, by shading tree. Therefore, agroforestry system provides not only an ecological advantage but also socioeconomic and cultural advantages (Beer, Muschler, Kass, \& Somarriba, 1998).

Shade trees which are commonly used for coffee plants in Rejang Lebong Regency are Erythrina lithosperma (dadap), Leucaena leucephala (lamtoro), Falcataria mollucana (sengon), Melia azedarach (mindi), and Gliricidia sepium (gamal). Those trees belong to Leguminosae family and have capability in binding $\mathrm{N}$ elements in the soil. In the last few years, marrango tree (Azadirachta excelsa Jack.) has been introduced in this regency as a shade tree for coffee plantations because marrango tree has been widely planted and generated high income in North Bengkulu Regency and Central Bengkulu Regency. The marrango tree has a mild-to-moderate canopy density $(<30 \%)$. Thus, coffee plants can still receive enough sunlight to grow and produce coffee beans. Furthermore, marrango tree produces wood that can be used as construction timber and fuel wood. The demand of marrango tree wood is increasing, whereas the availability of this timber is getting scarce; consequently, the price of marrango tree is becoming expensive. Many farmers do not know yet the advantages of using marrango tree as shade trees for coffee plantations in agroforestry systems. Therefore, some promotional efforts to show that this practice can be a profitable and alternative ways are necessary. Because profit is one of the considerations in the process of innovation adoption and practice of agroforestry to be accepted by farmers (Franzel, Coe, Cooper, Place, \& Scherr, 2001).

Financial analysis on agroforestry practiced by farmers is based on silviculture aspects or cultivation systems. This research is intended to find out whether the use of marrango tree for shading trees of coffee is profitable. Therefore it can be used to encourage farmers in practicing this cultivation system. This paper aims to analyze on agroforestry system of coffee with marrango tree. Moreover, the 
analysis also included (1) calculation of financial feasibility of the agroforestry system, and (2) sensitivity analysis to find out the resistance of agroforestry of coffee with marrango tree to the changes of coffee price, coffee production and wood price of marrango tree.

\section{MATERIAL AND METHOD}

\section{A. Study Sites}

Field research was conducted in Rejang Lebong Regency, Bengkulu Province, and Pal 100 village and Dataran Tapus village in Bermani Ulu Raya Sub-district were selected for data collection (Figure 1). The two villages were selected purposely because people has applied agroforestry of coffee plants with marrango tree. Coffee is the main source of income for people who live in these two villages. The number of households was 389 in Pal 100 Village and 323 in Dataran Tapus Village. The area is located at 102019' - 102057' East Longitude and 2022'07' - 3031' South Latitude. Rejang Lebong Regency is located at altitude between 500 and 2000 meters above sea level (BPS Bengkulu, 2013). Topographical conditions of Rejang Lebong Regency are hilly and mountainous.

\section{B. Data Collection}

The data collection was carried out in May and October 2013. It included direct observations, household surveys, and in-depth interviews. Key actors for in-depth interviews included village head, forest extension, and head of farmers, and it was conducted to deepen the information and verify the collected data.

The number of respondents from the household survey was 27 . They were purposely selected on condition that they planted or had at least 30 trees on each farmland. Since Rejang Lebong Regency is not the native growing area of marrango tree, farmers who plant marrango tree as shade tree for coffee is still limited, and some of them could not give enough information for this research. The collected data consists of respondents' characteristics (e.g. age, occupation, education, income, and owned land), land and crop management system, land prices, commodity prices, wood prices, and labor wage. Concurrently, secondary data, such as village monographs, community forest area, and other supporting data, were collected.

\section{Data Analysis}

Quantitative descriptive analysis, financial analyses, and sensitive analysis were employed to analyze the collected data. Quantitative

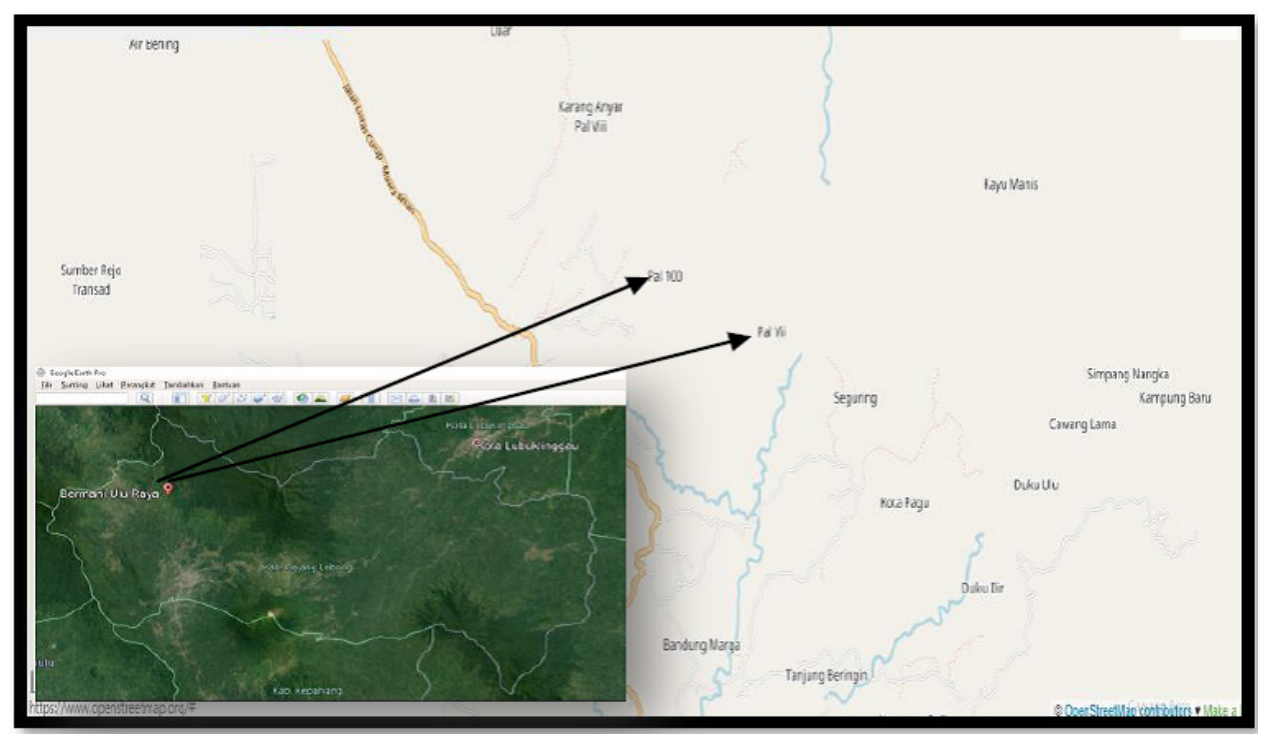

Figure 1. Map of the study area

Sources: https://www.openstreetmap.org; https:/www.google.com/ earth/ 
descriptive analysis was used to explain the management and cultivation practices carried out by the general farmers in the study site. Financial analysis was utilized to calculate the feasibility of agroforestry system applied by the respondents. The indicators of the financial analysis included Net Present Value (NPV), Internal Rate of Return (IRR), and Benefit Cost Ratio (BCR) (Gittinger, 1982; Kadariah \& Gray, 1999). In this study, the financial analysis was carried out by using the method of cash flow from the costs and revenues that were discounted. According to the key informants and most of the respondents, the rotation cycle of coffee was 20 years and marrango tree was 18 years. The stream of inputs (i.e. costs) and outputs (i.e. income) was adjusted based on the management undertaken by the farmers in the study area. Costs were calculated from the amount of the costs incurred from land clearing/land preparation through maintenance until the harvesting of marrango tree and the perennial crop. Costs incurred from land clearing for the annual maintenance of coffee and marrango tree were joint cost.

Assumptions for financial analysis (NPV, IRR, BCR) used in the study as incomes and expenses were based on key informants interview. The assumptions are as follows:

1. Price of land used in accordance with the conditions in the study site was IDR $20,000,000$ depending on the location of the land and road access.

2. The maintenance was performed from the first year until the end of the cycle.

3. Labor wage per day in the location of study was IDR 50,000 - for men and IDR 35,000 for women.

4. Business analysis of coffee plant was until the age of 20 years and marrango tree will be harvested at 18 years with estimated results in cubic was $0.607 \mathrm{~m}^{3}$ per tree.

5. The volume of marrango tree was calculated by using growth model of $V=-0.9280$ $5.9624 / A+0.7295 \mathrm{LnSi} 1.1365 \mathrm{LnN}$ (Siahaan, Sumadi, \& Saefuloh, 2012), where
$V$ is volume, $A$ is age of the tree; $N$ is number of marrango tree, and $S i$ is the site quality with value of 19.5 (location of the study).

6. Coffee plants produced the fruit started at the age of 2-3 years, reached the harvesting peak at the age of 4-5 years, then decrease and reached a stable production at the age of 7 years. After 7 years, the coffee will be rejuvenated to get a new branching and will begin to bear fruit after 1.5 years. At the age of 20 years, timber and coffee will be harvested simultaneously and replaced with new plants.

7. Coffee price based on the market price received by farmers during the study time, i.e. IDR 15,000 per kilogram for dried coffee bean (after removing the skin).

8. The price of marrango tree was the standing tree price that the volume is estimated by the buyer. Price of processed wood (sawn timber) at the farm level was IDR 2,000,000 per $\mathrm{m}^{3}$.

9. The cost of harvesting and processing the timber to get processed wood (board) was IDR 550,000 per $\mathrm{m}^{3}$.

10. The yield of processing wood into processed wood (board) was 0.6 because one tree with a volume of $1 \mathrm{~m}^{3}$ when processed into processed wood will produce $0.6 \mathrm{~m}^{3}$.

11. The interest rate for consumer loans at Local Government Bank at Bengkulu Province was $12.39 \%$ (Bank of Indonesia, 2013). The inflation was 4.39 in 2008-2012 (BPS, 2013). The discount factor used for the analysis is the commercial bank interest rate $(12.39 \%)$ - the annual inflation rate $(4.39)=8 \%$ (the real interest rate).

The sensitivity analysis was employed to determine the level of risk on conducting the agroforestry farming system. The indicators included the fluctutation of coffee and marrango tree production and price by $10 \%$ and $30 \%$, either simultaneously or separately. Those levels of sensitivity were chosen based on the information from the farmers about the current condition. 


\section{RESULT AND DISCUSSION}

\section{A. Agroforestry System of Coffee with Marrango tree in Rejang Lebong Regency}

In Rejang Lebong Regency, seasonal harvesting time of coffee is between April and August, and the peak of harvesting time is from May to June. The production ranged from 850 to $950 \mathrm{~kg} / \mathrm{ha}$ and it depended on the managements by each farmer in which the number of coffee plants ranged from 2,500 to 4,400 per hectare. However, in the off-season, the coffee trees bear fruits in smaller amounts. Thus, farmers usually conduct intensive management and maintenance of the coffee plantations only a few months per year before and during the fruit season (i.e., harvest time). Because routine maintenance, such as weeding and fertilizing, does not require a huge number of labor, it was done by only housemakers. Outside the harvest season, the heads of farmer households would try to find additional income from off-farm activities, such as construction workers, farm workers and carpenters, both inside and outside of their village. This situation affects the condition of the land and coffee production of the farmers because they do not have enough time to take care of their land.

Marrango tree grows naturally in North and Central Bengkulu Regencies, and the local people cultivate marrango tree on their private land for long time. Marrango tree is planted as intercrops, alley cropping and borders plants, with main crops such as rubber, oil palm, cocoa, and coffee. Marrango tree is suitable tree plants for mixed-cropping system because it has a mild-to-moderate canopy and root system that do not interfere with the main crops. According to the District Office of Forestry and Plantation of Rejang Lebong Regency, marrango tree has been widely introduced to the farmers through land rehabilitation program by this institution since 2000.

The first step of agroforestry of coffee with marrango tree was land preparation, either by clear cutting or by line cutting. Generally the lands that will be planted by the crops are covered by shrubs. After land preparation and lands were ready for plant, planting of coffee and the timber were conducted. The planting of these plants were started simultaneously the beginning of rainy season. Planting space commonly used for coffee was $1.5 \mathrm{~m} \times 1.5 \mathrm{~m}$ or $2 \mathrm{~m} \times 2 \mathrm{~m}$ and marrango tree was $6 \mathrm{~m} \times 7 \mathrm{~m}$ or $10 \mathrm{~m} \times 10 \mathrm{~m}$. Farmers manured before or after planting to accelerate the growth of coffee plants.

Weeding was carried out by cleaning the grass and other weeds in both manually and chemically ways. This activity was performed depending on the conditions in the land. Most farmers did this activity four times per a year and more intensively when the harvest season of coffee is almost coming. Trimming of coffee plants was conducted once per a year after the harvesting process was completed. Trimming was implemented to reduce leaves and increase coffee fruits. Thinning of the shading plants was conducted when the plants were attacked by disease and to prevent the spread of disease. Pesticide is usually applied to protect from pests and diseases. However, only some farmers implemented all of these management activities due to their lack of knowledge, skill, and economic capabilities.

Farmers obtained information and knowledge about farm management from fellow and elders of farmers, extension workers as well as from traders of fertilizers and seeds. Farm management in coffee and marrango tree agroforestry was applied at the same time, so that the cost structure of coffee and timber in this agroforestry model cannot be calculated separatedly. The cost is counted as a joint cost for both coffee plants and marrango tree, for example coffee crop fertilization activities were conducted at the same time with the fertilization of marrango tree plants.

Simultaneous management of marrango tree and coffee plants could reduce labor costs and inputs such as fertilizers and herbicides. The standard recommended dosage and use of fertilizer was not followed by some farmers due 


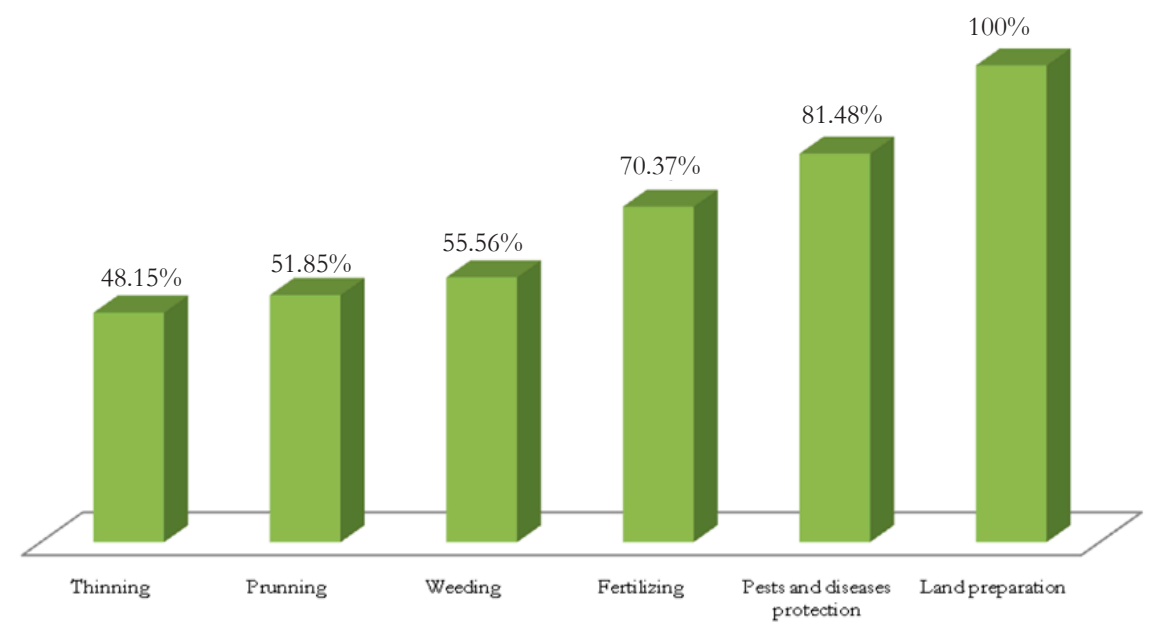

Figure 2: Distribution of respondents according to implemented management of coffee and marrango tree agroforestry

Sources: Processed data (2013)

to their lack of capital, both economical capital and human capital. Maintenance of marrango tree is conducted intensively at the age 1-3 years after planting. Routine maintenance was only for weeding and pruning branches, because marrango tree is more resistant to pests and disease. In terms of silviculture, intensification techniques, Bell et al.(2008) mentioned that the coffee plants and marrango tree agroforestry management could be categorized as the basic level cultivation headed toward intensive silviculture.

Figure 2 show that all respondents implemented land preparation (100\%), 81.48\% of them applied pest and disease protection/ control, and $70.37 \%$ of them conducted fertilization. However, thinning and pruning were conducted only by $48.15 \%$ and $51.85 \%$ respondents respectively. Based on interviews with some respondents, they did more intensive maintenance activities to coffee (pest and desease protection, and also fertilization). On the other hand, in terms of marrango tree, the maintenance activities were very limited. This result explains that agroforestry practice in Rejang Lebong Regency is still simple and semi-commercial, for which cultivation aspects to increase productivity such as selection of seeds, fertilization, weeding, thinning, pest control and proper harvesting system have not yet been conducted properly by farmers. Lack of information, knowledge, capital and access to markets are the limiting factors of farmers to apply the proper cultivation techniques.

\section{B. Cost and Revenue of Agroforestry of Coffee with Marrango Tree}

The cost of agroforestry of coffee with marrango tree consists of many inputs. Land preparation to get ready for planting takes some time, around 3-4 months, depending on the condition of the land, starting from the cutting of trees and stems, land clearing and fencing. Revenue of the agroforestry was calculated from the production of coffee and marrango tree as the major components. For other products income (e.g., vegetables, chili, tomato, etc) was not calculated because there were no accurate data available and they were only for self consumption. Moreover, it was only done by a few farmers in small quantities. The costs and revenues of agroforestry of coffee with marrango tree are presented in Table 1.

Establishment costs of the agroforestry of coffee with marrango tree included land investment, land preparation, seed procurement, planting, weeding, fertilizing and harvesting. The highest expenditure was harvesting of 
Table 1: Cost and revenue from coffee and marrango tree agroforestry

\begin{tabular}{|c|c|c|c|c|c|}
\hline No. & Cost Component & Unit & Frequency (Year) & $\begin{array}{c}\text { Value (IDR/ } \\
\text { Ha) }\end{array}$ & $\begin{array}{c}\text { Proportion } \\
(\%)\end{array}$ \\
\hline 1. & Land investment & $\mathrm{IDR} / \mathrm{Ha}$ & 0 & $20,000,000$ & 20.25 \\
\hline 2. & Land preparation & $\mathrm{IDR} / \mathrm{Ha}$ & 1 & $3,350,000$ & 3.39 \\
\hline 3. & Seed & $\mathrm{IDR} / \mathrm{Ha}$ & 1 & $2,687,500$ & 2.72 \\
\hline 4. & Planting & $\mathrm{IDR} / \mathrm{Ha}$ & 1 & $10,400,000$ & 10.53 \\
\hline 5. & Handling & $\mathrm{IDR} / \mathrm{Ha}$ & Yearly & $6,300,000$ & 6.38 \\
\hline 6. & Fertilizing & $\mathrm{IDR} / \mathrm{Ha}$ & Yearly & $18,270,000$ & 18.50 \\
\hline 7. & Equipment & Unit & Yearly & $2,240,000$ & 2.27 \\
\hline \multirow[t]{9}{*}{8.} & Harvesting & & & & \\
\hline & - Coffee & $\mathrm{IDR} / \mathrm{Ha}$ & Average per year & $2,121,000$ & 2.15 \\
\hline & - Marrango tree & $\mathrm{IDR} / \mathrm{Ha}$ & Once & $33,385,000$ & 33.81 \\
\hline & Sub Total & & & $98,753,500$ & 100 \\
\hline & Revenue & & & & \\
\hline & 1. Coffee & $\mathrm{IDR} / \mathrm{Ha}$ & & $227,250,000$ & 65.18 \\
\hline & 2. Marrango tree & $\mathrm{IDR} / \mathrm{Ha}$ & The rotation is 18 years & $121,400,000$ & 34.82 \\
\hline & Sub Total & & & $348,650,000$ & 100 \\
\hline & Revenue - costs & & & $249,896,500$ & \\
\hline
\end{tabular}

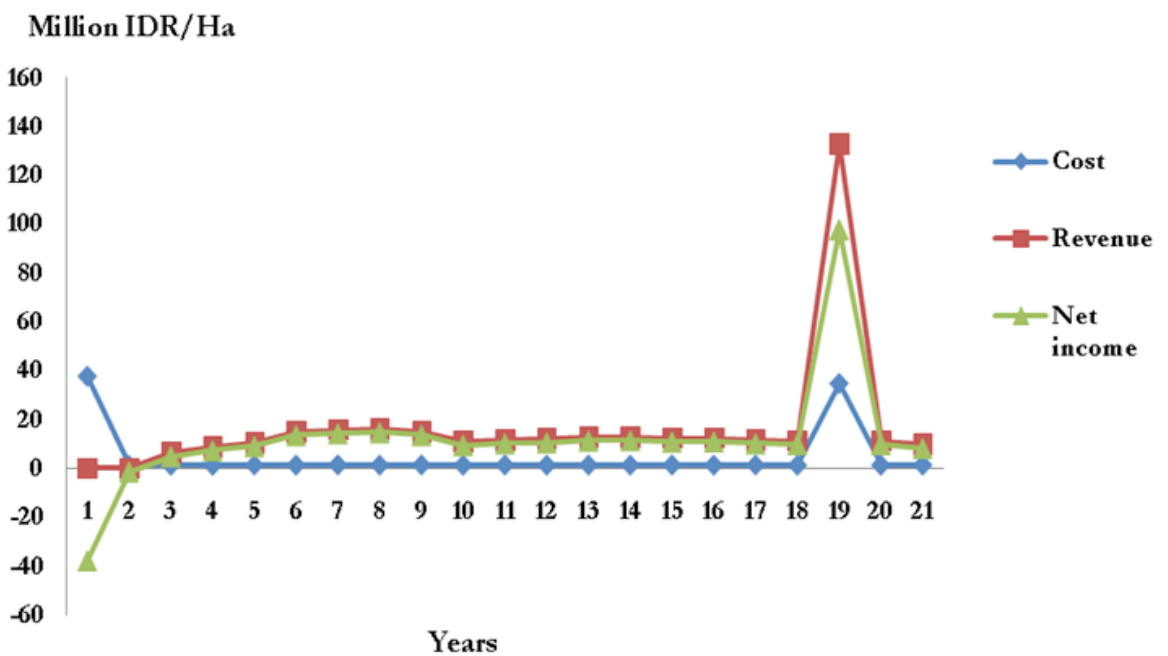

Figure 3. Cash flow of coffee and marrango tree agroforestry

Sources: Processed data (2013)

timber (33.81\%), while the second was land investment (20.25\%). Fertilization activities (inputs and wages) were relatively not too costly $(18.50 \%)$ because this agroforestry model can maintain the soil fertility and nutrient availability. According to Mindawati, Kosasih, and Heryati, (2006), planting several types of forest crops can improve soil fertility by increasing the number and activity of microorganisms, and increasing the number of functions in the soil.
This condition was in line with research results conducted by Lakshmi and Ammini, (2016); Sudomo and Handayani, (2013); Rao, Nair, and Ong (1998) who stated that agroforestry could improve the biophysical condition of the soil and also improve soil fertility. Land was included as a cost component because it was acquired by purchase and became part of the investment in which the value of the land will increase at the end of the cycle. Although some 
Table 2. NPV, BCR and IRR of agroforestry coffee and marrango tree at discounted factor 8\%

\begin{tabular}{|c|c|c|c|c|c|c|c|c|}
\hline \multirow[b]{2}{*}{$\begin{array}{l}\text { (Interest } \\
\text { rate } \% \text { ) }\end{array}$} & \multicolumn{3}{|c|}{ Nominal value } & \multicolumn{2}{|c|}{ Discounted value } & \multirow[b]{2}{*}{$\begin{array}{l}\text { NPV } \\
\text { (IDR) }\end{array}$} & \multirow[b]{2}{*}{ BCR } & \multirow[b]{2}{*}{$\begin{array}{l}\text { IRR } \\
(\%)\end{array}$} \\
\hline & $\begin{array}{l}\text { Total Cost } \\
\text { (IDR/Ha) }\end{array}$ & $\begin{array}{c}\text { Total } \\
\text { Revenue } \\
\text { (IDR/Ha) }\end{array}$ & $\begin{array}{c}\text { Profit } \\
\text { (IDR/Ha) }\end{array}$ & $\begin{array}{l}\text { Total Cost } \\
\text { (IDR/Ha) }\end{array}$ & $\begin{array}{c}\text { Total } \\
\text { Benefit } \\
\text { (IDR/Ha) }\end{array}$ & & & \\
\hline 8 & $98,753,500$ & $348,650,000$ & $249,896,500$ & $59,591,294$ & $135,841,875$ & $76,250,582$ & 2.28 & 22 \\
\hline
\end{tabular}

Sources: Processed data (2013)

farmers inherited the land from their ancestors without buying the land, this analysis assumed that all the farmers purchased the land.

Cash flow in the agroforestry of coffee with marrango tree is very dependent on the production of coffee crops per year, coffee commodity prices that often fluctuate during the harvest season, the price of marrango tree and climate that affect the quality and production. According to Slingo et al., (2005), climate change can affect the temperature and extreme precipitation that can influence the production and quality of crops, including coffee. Coffee production is the most influential factor in the analysis because it will be affected by climate and the management system. In addition, the price level also have an influence on the analysis as it is related to the availability/abundance of the commodity. Cash flow on the land use pattern also is influenced by the pattern of timber harvesting, land management systems, and biophysical conditions. Therefore, all of the risks that may affect the cash flow should be taken into account in the sensitivity analysis.

\section{Financial Analysis of Coffee and Marrango Tree Agroforestry}

Revenues were all incomes received from the perennial crop and timber (coffee plants and marrango tree). Income derived from intercrops in the early stages of the plantation, such as chilli, tomato and vegetables, was not included because data was not available at the time of the study. The amount of the revenue depends on the prices and production of coffee and timber. Perennial crop production varied each year depending on the age of the plant. It increases up to a certain age and decline the following year. In addition, the weather also affects the production and harvesting time of coffee. The production depend on the maintenance of the farmers, such as fertilization, weeding and pest control.

Units used in the assessment were per hectare unit. At 8\% interest rate (discount factor), the NPV of the agroforestry of coffee and marrango tree was IDR 76,250,582; the BCR was 2.28 and the IRR was $22 \%$ (Table 2). These results showed that the agroforestry system of coffee with marrango tree was financially feasible to be developed.

The result of this financial analysis was in line with Siregar, Rachmi, Massijaya, Ishibashi, and Ando (2007), in which in East Java, agroforestry of sengon plants and agricultural crops also had a fairly high rate $(17.53 \%)$ of benefits. Various studies also claimed that planting trees in coffee agroforestry is more profitable compared to the monoculture cultivation of coffee (Mehta \& Leuschner, 1997; Kiyingi \& Gwali, 2012; Ginoga, et al, 1999, Miller \& Schaal, 2006; Schaller, et al, 2003). Other study mentioned that coffee agroforestry with different shading woody plants and Multi Purpose Tree Species (MPTS) also provides advantages from the standpoint of the farmers (Prasmatiwi, Irham, Suryantini, \& Jamhari, 2010). In contrast, Saxena, (1991) expressed the opposite opinion that planting trees with annual crops would give negative results. Therefore, in the tree planting, the biophysical conditions, plant spacing and plant density should be considered to avoid the diminishing of the annual crop production. Bosselmann et al., (2009) and Schaller et al. 
(2003) also stated that shading trees in coffee agroforestry reduce the production of coffee.

The proportion of revenue from timber was $34.82 \%$ and $65.18 \%$ from coffee. Wood product in this agroforestry model provided a large income at the end of the cycle even though wood is not the primary object to serve as a source of revenue. The quality and quantity of timber in this agroforestry model was not a major focus of the farmers due to the length of harvesting time. Wood products have functions to meet non-periodic needs and as savings.

Agroforestry systems can support better timber growth compared to natural forests, due to better input and also because of the reduction of light competition by setting desired plant density and plant canopy (Nath, et al, 2011). Furthermore, Nath et al. (2011) revealed that native tree planting is better than exotic trees. Campanha et al. (2005) stated that the growth of trees in agroforestry systems of coffee is quite good but the production of coffee is smaller than in monoculture cropping systems. Worku et al. (2015) explained that coffee production life will be longer and resistant to disturbances such as climate change in agroforestry system along with the trees. Those findings could be applied by farmers in agroforestry of coffee plants and marrango tree.

\section{Sensitivity Analysis of Coffee and Marrango Tree Agroforestry}

Sensitivity analysis is intended to examine a variety of potential changes and errors, as well as the impact of decisions described from the model (Baird, 1989 in Pannell, 1997). The sensitivity analysis was performed to see the flexibility and/or resistance and sensitivity of the business due to the change in inputs and outputs. Farmers are often faced with uncertainty in business due to the limited ability to predict the changes of the weather, the price and the biological response that affected their business practice (Pannell, Malcolm, \& Kingwell, 2000). Climate change that has occurred in recent years led to a decrease in coffee production. According to Rosenzwei et al. (2001), climate change will affect crop production and the breeding of pests and diseases significantly. Coffee prices were fluctuating during the last few years, so it can affect the results of the analysis. In general, the price of wood including marrango tree has increased each year that were affected by the transportation costs and scarcity of wood. Results of the sensitivity analysis on agroforestry of coffee with marrango tree was shown in Table 3.

Table 3. Sensitivity analysis of coffee and marrango tree agroforestry at $8 \%$ discount rate

\begin{tabular}{|c|c|c|c|c|}
\hline \multirow{2}{*}{$\begin{array}{c}\text { Agroforestry of coffee plants } \\
\text { and marrango tree }\end{array}$} & \multirow{2}{*}{ Change $(\%)$} & \multicolumn{3}{|c|}{ Investment Criteria } \\
\hline & & NPV (IDR/Ha) & BCR & $\operatorname{IRR}(\%)$ \\
\hline \multirow[t]{2}{*}{ Coffee production } & -10 & $60,804,425.72$ & 2.05 & 20 \\
\hline & -30 & $39,504,253.70$ & 1.69 & 16 \\
\hline \multirow[t]{2}{*}{ Marrango tree production } & -10 & $68,804,425.72$ & 2.19 & 22 \\
\hline & -30 & $64,144,783.82$ & 2.11 & 21 \\
\hline \multirow{4}{*}{$\begin{array}{l}\text { Coffee and marrango tree } \\
\text { price }\end{array}$} & $-10 ;+10$ & $58,263,261.40$ & 2.01 & 20 \\
\hline & $-10 ;+30$ & $67,592,545.20$ & 2.17 & 20 \\
\hline & $-30 ;+10$ & $41,835,574.65$ & 1.73 & 16 \\
\hline & $-30 ;+30$ & $46,500,216.55$ & 1.81 & 17 \\
\hline \multirow{2}{*}{$\begin{array}{l}\text { Coffee and marrango tree } \\
\text { production }\end{array}$} & -10 & $58,263,261.40$ & 2.01 & 20 \\
\hline & -30 & $32,506,290.84$ & 1.56 & 15 \\
\hline \multirow{5}{*}{$\begin{array}{l}\text { Coffee and marrango tree } \\
\text { production and price }\end{array}$} & $-10 ;+10$ & $56,001,908.45$ & 1.97 & 18 \\
\hline & $-10 ;+30$ & $67,197,049.02$ & 2.17 & 19 \\
\hline & $-30 ;+10$ & $22,254,182.61$ & 1.39 & 12 \\
\hline & $-30 ;+30$ & $33,449,323.17$ & 1.58 & 14 \\
\hline & $-30,-30$ & $9,772,886.98$ & 1.17 & 10 \\
\hline
\end{tabular}


The analysis showed that the decline in coffee production by $30 \%$ and a decrease in the production of marrango tree by $30 \%$ can still provide feasibility. From the NPV results above, we can observe that changes in the production and price of coffee is the most influential factor on the feasibility of agroforestry of coffee plants with marrango tree. This decrease in production is generally due to pest attack, season and plant maintenance. Based on the sensitivity analysis, the model of agroforestry was not sensitive to the changes that occurred when the production of coffee and marrango tree decreased up to $30 \%$ and the price only increased by $10 \%$. Accordingly, it can be considered to be applied in the farmers' lands.

Since agroforestry system of coffee with marrango tree was beneficial for the farmers, local and central government can support the development of agroforestry system in the regency by utilizing their power, budget and regulation. In case of Japan, the government gave subsidy in order to improve people's timber business (Ota, 2001 in Rohadi, 2012). Thus, the community will have more eagerness to plant timber tree because there was an incentive for farmers in the form of loan with low interest rate and high quality seeds to increase productivity. In Rejang Lebong Regency as the study location, department of forestry and plantations had provided timber seeds to the communities in the 2000s with the consideration that marrango tree has good wood quality and can be used as shade trees for coffee plants.

\section{CONCLUSION}

Farmers obtained information and knowledge about farm management from fellow farmers, the elderly, extension workers and also from traders of fertilizers and seeds. Management of agroforestry includes land preparation, planting, fertilization, weeding, pruning, thinning, pest and disease protection, and harvesting. However, only $21.62 \%$ of farmers implemented all of these farming management activities, due to their lack of knowledge, skill and economic capabilities.

Cost incurred for the development of agroforestry of coffee plants and marrango tree is IDR 98,753,500 per hectare for one cycle (20 years), while the revenue obtained during one cycle is IDR 348,650,000. The proportion of revenue from timber was $34.82 \%$ and from coffee $65.18 \%$. Marrango tree has a smaller portion of the revenue than coffee, however, marrango tree still provided a quite large income at the end of the cycle.

Agroforestry of coffee plants and marrango tree was financially feasible at the level of $8 \%$ discounted rate. In which the NPV, BCR and IR were IDR $76,250,582 ; 2.28$ and $22 \%$ respectively. The coffee and marrango tree agroforestry has a good resistance to the changes in coffee price, coffee production and wood price of marrango tree. Changes in the production and price of coffee are the most influential factors on the feasibility of the agroforestry system of coffee plants and marrango tree. Since agroforestry system of coffee with marrango tree is beneficial for the farmers, the local government should encourage the community to apply this system. However, this result applies only in Rejang Lebong Regency, Bengkulu province. Therefore, further analysis is needed if it will be applied to other locations.

\section{ACKNOWLEDGEMENT}

We would like to express our deep gratitude to The Head of Forestry Research Institute of Palembang, Ir. Suhariyanto, MM. for the support during the research.

\section{REFERENCES}

Beer, J., Muschler, R., Kass, D., \& Somarriba, E. (1998). Shade management in coffee and cacao plantations. Agroforestry System, 38, 139164.

Bell, F. W., Parton, J., Stocker, N., Joyce, D., Reid, D., Wester, M., ... Towill, B. (2008). Developing a silvicultural framework and definitions for use 
in forest management planning and practice, The Forestry Chronicle, 84(5) 678-693.

Bosselmann, A. S., Dons, K., Oberthur, T., Olsen, C. S., Ræbild, A., \& Usma, H. (2009). The influence of shade trees on coffee quality in smallholder coffee agroforestry systems in Southern Colombia. Agriculture, Ecosystems and Environment, 129(1-3), 253-260. doi:10.1016/j. agee.2008.09.004.

BPS Bengkulu. (2013). Bengkulu Province in figures. BPS-Statistics of Bengkulu Province.

BPS Rejang Lebong. (2013). Gross regional domestic product of Rejang Lebong Regencies. BPSStatistics of Rejang Lebong Regencies.

Campanha, M. M., Santos, R. H. S., De Freitas, G. B., Martinez, H. E. P., Garcia, S. L. R., \& Finger, F. L. (2005). Growth and yield of coffee plants in agroforestry and monoculture systems in Minas Gerais, Brazil. Agroforestry Systems, 63(1), 75-82. doi:10.1023/ B:AGFO.0000049435.22512.2d.

Evizal, R., Tohari, Prijambada, I. D., \& Widada, J. (2012). The role of litter on $\mathrm{N}$ and $\mathrm{P}$ retrun in coffee agro-ecosystems. Agrotropica Journal, 2(2), 177-183.

Franzel, S., Coe, R., Cooper, P., Place, F., \& Scherr, S. . (2001). Assessing the adoption potential of agroforestry practices in Sub-Saharan Africa. Agricultural Systems, 69(1), 37-62.

Ginoga, K., Cacho, O., Lugina, M., \& Djaenudin, D. (1999). Economic performance of common agroforestry systems in Southern Sumatera: Implications for carbon sequestration services. Economic Analysis, 1-21.

Gittinger, J. P. (1982). Economic analysis of agricultural projects. Baltimore, Maryland USA: The John Hopkins University Press.

Jose, S. (2009). Agroforestry for ecosystem services and environmental benefits: An overview. Agroforestry Systems, 76(1), 1-10. doi:10.1007/ s10457-009-9229-7.

Kadariah, L. K., \& Gray, C. (1999). Introduction of project evaluation. Jakarta: Publisher Institute Faculty of Economics, University of Indonesia.

King, K. F. S., \& Chandler, M. T. (1978). The wasted land. Nairobi, Kenya: ICRAFT.

Kiyingi, I., \& Gwali, S. (2012). Productivity and profitability of robusta coffee agroforestry systems in central Uganda. Uganda Journal of Agricultural Sciences, 13(1), 85-93.
Lakshmi, G., \& Ammini, J. (2016). Soil Microarthropods as indicators of soil quality of tropical home gardens in a village in Kerala, India. Agroforestry Systems, 91(3), 439590. doi:10.1007/s10457-016-9941-z.

Lin, B.B. (2008). Microclimate effects on flowering success in coffee agroforestry systems. American Eurasian Journal Agricultural and Environmetal Science, 3(2), 148-152.

Mehta, N. G., \& Leuschner, W. A. (1997). Financial and economic analyses of agroforestry systems and a commercial timber plantation in the La Amistad biosphere reserve, Costa Rica. Agroforestry Systems, 37(2), 175-185. doi:10.1023/A:1005840524116.

Miller, A.J., \& Schaal, B.A. (2006). Domestication and the distribution of genetic variation in wild and cultivated populations of the mesoamerican fruit tree Spondias purpurea L. (Anacardiaceae). Molecular Ecology, 15(6), 14671480. doi:10.1111/j.1365-294X.2006.02834.x.

Mindawati, N., Kosasih, A. S., \& Heryati, Y. (2006). Effect of planting of forest trees to several types of fertility conditions andosol soil. Journal of Plantation Forest Research, 3(3), 155164.

Moorhead, D.J., \& Dickens, E.D. (2012). Agroforestry: A profitable land use. An overview of the $12^{\text {th }}$ North American Agroforestry Conference. Agroforestry Systems, 86(3), 299-302. doi:10.1007/s10457-0129581-x.

Muschler, R. G. (2008). Shade management and its effect on coffee growth and quality. Coffee: Growing, Processing, Sustainable Production: A Guidebook for Growers, Processors, Traders, and Researchers, 391-418. doi:10.1002/9783527619627.ch14.

Nath, C. D., Pélissier, R., Ramesh, B. R., \& Garcia, C. (2011). Promoting native trees in shade coffee plantations of southern India: Comparison of growth rates with the exotic Grevillea robusta. Agroforestry Systems, 83(2), 107-119. doi:10.1007/s10457-011-9401-8.

Pannell, D. J. (1997). Sensitivity analysis of normative economic models: Theoretical framework and practical strategies. Agricultural Economics, 16(2), 139-152.

Pannell, D. J., Malcolm, B., \& Kingwell, R. S. (2000). Are we risking too much? perspectives on risk in farm modelling. Agricultural Economics, 23, 69-78. 
Perfecto, I., Rice, R. A., Greenberg, R., \& Voort, M. E. Van Der. (1996). Shade coffee: A disappearing refuge for biodiversity. BioScience, 46(8), 598-608.

Prasmatiwi, F. E., Irham, Suryantini, A., \& Jamhari. (2010). Sustainability analysis of coffee farming in protected forest of West Lampung based on enviromental economic value. Pelita Perkebunan, 26(1), 57-69.

Rao, M. R., Nair, P. K. R., \& Ong, C. K. (1998). Biophysical interactions in tropical agroforestry systems. Agroforestry Systems, 38(5), 3-50. doi:10.1023/A:1005971525590.

Rohadi, D. (2012). Analysis of farmer's perceptions and strategies in smallbolder timber plantation business (Case studies of smallholder timber plantations at gunungkidul district, special Province of Yogyakarta and Tanah Laut District, Province of South Kalimantan). (Thesis). Bogor Agricultural University, Bogor.

Rosenzweig, C., Iglesius, A., Epstein, P. R., \& Chivian, E. (2001). Climate change and extreme weather events - Implications for food production, plant diseases and pests. Glob. Change Human Health, 2, 90-104.

Sari, N. P., Santoso, T. I., \& Mawardi, S. (2013). Distribution of soil fertility of smallholding arabica coffee farms at Ijen-Raung highland areas based on altitude and shade trees. Pelita Perkebunan, 29(2), 93-107.

Saxena, N. C. (1991). Crop losses and their economic implications due to growing of Eucalyptus on field bunds - A pilot study. Agroforestry Systems, 16(3), 231-245. doi:10.1007/BF00119320.
Schaller, M., Schroth, G., Beer, J., \& Jiménez, F. (2003). Species and site characteristics that permit the association of fast-growing trees with crops: The case of Eucalyptus deglupta as coffee shade in Costa Rica. Forest Ecology and Management, 175(1-3), 205-215. doi:10.1016/ S0378-1127(02)00079-8.

Siahaan, H., Sumadi, A., \& Saefuloh, T. (2012). Kayu bawang. Research report. Forestry Research Institute, Palembang.

Siregar, U. J., Rachmi, A., Massijaya, M. Y., Ishibashi, N., \& Ando, K. (2007). Economic analysis of sengon (Paraserianthes falcataria) community forest plantation: A fast growing species in East Java, Indonesia. Forest Policy and Economics, 9(7), 822-829. doi:10.1016/j. forpol.2006.03.014

Slingo, J. M., Challinor, A. J., Hoskins, B. J., \& Wheeler, T. R. (2005). Introduction: food crops in a changing climate. Philosophical Transactions of the Royal Society of London. Series B, Biological Sciences, 360(1463), 1983-9. doi: 10.1098/rstb.2005.1755.

Sudomo, A., \& Handayani, W. (2013). Soil characteristic of four types of trees-kapulaga based agroforestry system (Amomum compactum Soland ex Maton). Jurnal Penelitian Agroforestry, 1(1), 1-11.

Worku, M., Lindner, A., \& Berger, U. (2015). Management effects on woody species diversity and vegetation structure of coffeebased agroforestry systems in Ethiopia. SmallScale Forestry, 14(4), 531-551. doi:10.1007/ s11842-015-9305-y. 